認定医ケースプレゼンテーション抄録

歯冠内アタッチメントを用い天然歯と連結したインプラント補経症例 平 曜輔

\title{
A Clinical Case Report of Implant Supported Restoration Connected with Natural Tooth Using an Intracoronal Attachment
}

Taira Yohsuke

\section{I. 症例の概要}

患者: 33 歳 (初診時), 女性.

初診: 平成 2 年 7 月.

主訴：右下臼歯部ブリッジの動摇.

(7)6(5)|ブリッジの動摇を主訴に来院された。7忚 失活歯であり, 装着されている築造体の周囲と全部鋳 造冠の辺縁には，㽬蝕による著しい歯質の崩壊が認め られた。

\section{II. 診断と治療方針}

77 は $\mathrm{C}_{4}$ で抜歯適応であること（図 1 )，局部床義 歯やインプラントを用いた補綴が考えられることを患 者に説明した. 抜歯後 76 暫間義歯を装着したうえで 再度確認したところ，インプラントによる治療を希望 された. 問診, 視診, 触診, 研究用模型による診査, さらに抜歯から 7 カ月後に下顎骨を試験穿針してパノ ラマ X 線撮影を行い, 検討した結果，インプラント 埋入可能と判断した（図 2)。また，7的 $2,6 \sqrt{7}$ は $\mathrm{C}_{3}$ であった。

長崎大学大学院医歯薬学総合研究科医療科学専攻発生分化機能再 建学講座捸食機能回復診断治療学分野

Division of Fixed Prosthodontics and Oral Rehabilitation, Department of Developmental and Reconstructive Medicine, Course of Medical and Dental Sciences, Nagasaki University Graduate School of Biomedical Sciences
III. 治療内容

平成 2 年 7 月, 5 の遠心部でブリッジを切断, 除 去し，7友歯した。平成 3 年 3 月，6遠心相当部 に IMZ システム (フリアデント) のインプラント体 （直径 $4 \mathrm{~mm}$, 長さ $13 \mathrm{~mm}$ ) を 1 本埋入し，10月に上 部構造を装着した。上部構造は7(7)6(5)ブリッジに準 じた形態とし， 61ポンティックと5修復物の間にア タッチメント（ベーラー, 井上アタッチメント）を用 いた。 $6 \sqrt{7}$ は抜髄と支台築造を施し, 全部鋳造冠を 装着した。7」はコンポジットレジンで修復した。

\section{IV. 経過観察と考察}

上部構造装着から 2 週間, 1,3 力月後, 以降は 6 力月抢きに経過を観察した。 今回用いたスライド式 アタッチメントは，スクリュー固定式のようにごく小 さなスクリューは使用しないため，内部可動性緩圧機 構 (IME) 交換の際は誤飲させる心配が少なく，上 部構造の着脱も比較的容易であった. 口腔内から撤去 された IME や粘膜貫通延長部（TIE）の表面には, プラークなどの污染物質が付着しているのが観察され た。

上部構造の装着から 11 年経過後はインプラント周 囲歯肉がわずかに退縮していたこと以外は，インプラ ントと司支台歯そして上部構造に著明な変化は認め られず，良好に機能していた（図 3）。

一般に骨結合型インプラントと天然歯を連結した場 


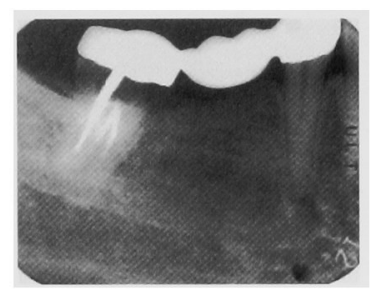

図 1 Dental X-ray radiography at the first examination 初診時のデンタル X 線写真
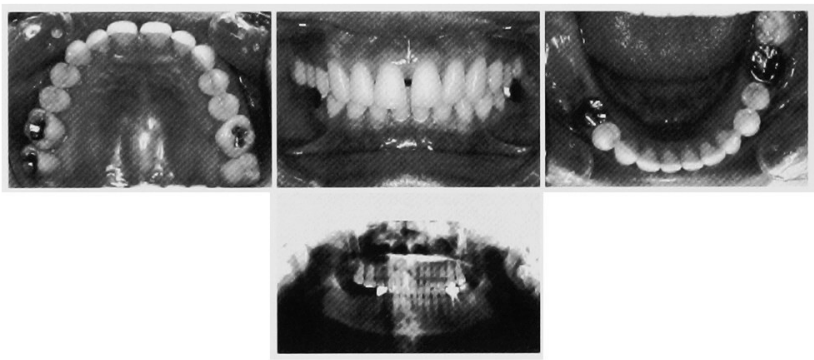

図 2 Intraoral views and orthopantomography before the treatment with dental implant インプラント処置前の口腔内写真とパノラマ X 線写真

合，インプラントの破折，骨吸収，天然歯の破折，二 次瀜蝕などの偶発症が報告されている11. また，荷重 時のインプラントと天然歯の変位量の差が原因で天然 歯が沈下し，スライド式アタッチメントに段差が生じ ることも知られている2⿰. 幸い本症例においては，こ のような偶発症は認められなかった。その理由とし て，プラークコントロールや咬合時に支台装置に加わ る荷重とその方向に問題が少なかったこと²，IMEの 被圧変位量が天然歯に近いこと ${ }^{4)}, \mathrm{IME}$ と TIEの交 換を比較的短い 6 力月間隔で行ったこと，アタッチメ ント部の摩擦力が適度に強かったことなどが推察され

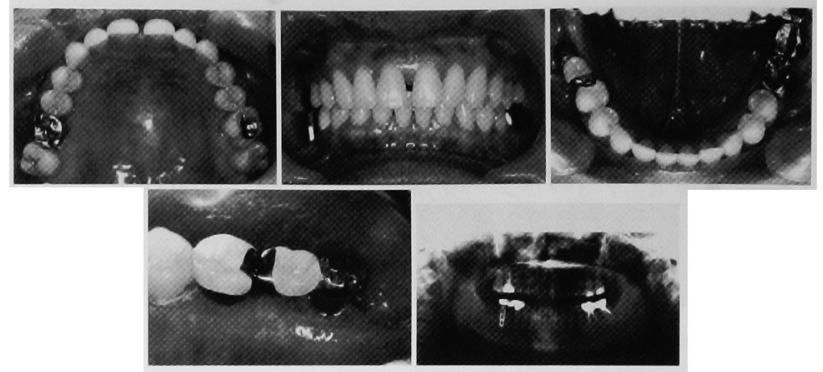

図 3 Intraoral views and orthopantomography 11 years after the treatment 11 年経過後の口腔内写真とパノラマ X 線写真

る.

本インプラント体深部の表面はプラズマスプレー処 理された粗面であるため，もし口腔内に露出すると， プラークコントロールが難しくなる可能性が高い.し たがって, 今後も引き続いて定期的な口腔清掃指導, 咬合変化の観察と調整，歯肉退縮には特に注意を払わ なければならないと考える。

\section{文献}

1）渡辺 浩, 松島弘季, 藤野 茂ほか. 骨結合型インプラントと 天然歯の連結症例について. 日ロ腔インプラント誌 13 ： 146-154, 2000.

2）澤瀬 隆. インプラントと天然歯の連結に考虑した一症例. 補 緅誌 45：452-453, 2001.

3) Esposito M, Hirsch JM, Lekholm U et al. Biological factors contributing to failures of osseointegrated oral implants. (I) Success criteria and epidemiology. Eur J Oral Sci 106 : 527-551, 1998.

4) Haganman CR, Holmes DC, Aquilino SA et al. Deflection and stress distribution in three different IMZ abutment designs. J Prosthodont 6:110-121, 1997. 